cannot be ruled out. It may be concluded that factors of hydranth regeneration largely involve reorientation of the cellular configuration in the available material. A detailed report on the manner of cell disposition and its relation to morphogenesis in hydra will be published elsewhere ${ }^{5}$.

Zusammenfassung. An regenerierenden Süsswasserpolypen (Hydra vulgaris orientalis) wurde die Gesamtmenge der Epithelmuskelzellen, der interstitiellen Zellen und der Cnidoblasten bestimmt. Dabei wurden sehr grosse Zellverluste, speziell bei den interstitiellen Zellen,

\section{A Possible Correlation Between Reverse Mutation and Complementation}

Results obtained in Neurospora crassa (see FinchaM ${ }^{1}$ for references) indicate that mutants exhibiting intra-locus complementation in a heterokaryon form a protein (C.R.M.) related serologically to the functional enzyme of the wild-type strain. Non-complementing mutants form apparently no C.R.M. Recently CRICK et al. ${ }^{2}$ have suggested that mutations induced by proflavine and the majority of spontaneous mutations ( FREESE $^{3}$ ) are due to the addition or subtraction of base pairs in the DNA, and result in the formation of no specific protein or to one greatly different from the wild-type.

These results may perhaps indicate that mutants arising by addition-subtraction type mutation would produce no C.R.M., and hence be non-complementing when occurring at loci at which intra-locus complementation is known to occur.

Mutants of the complementing type might be expected to be due to transition type mutations, affecting only one base pair of one triplet (FREESE ${ }^{3}$ ), and having only one amino acid difference between C.R.M. and the wild-type enzyme (WitrmanN ${ }^{4}$ ). If this hypothesis is true, complementing mutants would revert on treatment with mutagens causing transitions, such as base-analogues and nitrous acid.

True non-complementing mutants, besides producing no C.R.M., might be expected not to revert with mutagens causing transitions. Further, if no, or only a grossly altered protein is produced they would not be expected to be leaky or temperature-sensitive mutants. Results obtained by LeUpoL. ( ${ }^{5}$ and personal communication) for the ad-1 and ad-6 loci of Schizosaccharomyces pombe show at least 38 of the 40 incompletely blocked mutants tested to be of the complementing type.

\section{Presynaptic Inhibition in the Lumbar Cord Evoked from the Brain Stem}

It has recently been shown that the presynaptic terminals of primary afferents may be depolarized through spinal reflex actions and that synaptic actions to motoneurones by this mechanism may be inhibited ${ }^{2}$. Ta afferents are depolarized from group I afferents predominantly of flexor muscles, the flexor reflex afferents (FRA), on the other hand, from group I afferents and the FRA. Primary afferents may also be depolarized from higher centres, volleys in the pyramidal tract depolarize Ib, cutaneous and high threshold muscle afferents but not Ia afferents ${ }^{2}$. in geringerem Masse bei den Epithelmuskelzellen festgestellt. Die Zahl der Cnidoblasten nahm dagegen etwas zu.

S. SANYAL

Department of Zoology, Presidency College, Calcutta (India), June 7, 1962.

5 This investigation was supported by a grant-in-aid from the Council of Scientific and Industrial Rescarch to Dr. S. MookerjeE, Head of the Department of Zoology. I am thankful to him for suggestions and guidance, and to $C S I R$ for the award of a research fellowship.

Preliminary results obtained with ten mutants at the ad-1 locus of Schiz. pombe indicate that at least five of six complementing mutants will revert after treatment with nitrous acid. Three of the four non-complementing mutants will not do so. The fourth non-complementing mutant responds to nitrous acid treatment. It should be pointed out, however, that classification of a mutant as non-complementing is to some extent uncertain, since a given mutant may complement with very few other mutants at the same locus (CATCHESIDE ${ }^{6}$ ).

This hypothesis, that non-complementing point mutations producing no C.R.M. will not give true backmutation on treatment with nitrous acid, and other transition-type mutagens, is open to test at a number of loci in Neurospora (CATCHEside ${ }^{7}$ ) Schizosaccharomyces and Salmonella (Hartman, Hartman and Serman ${ }^{8}$ ).

Résumé. Les mutants présentant la complémentation intra-allélique sont probablement susceptibles aussi de mutation reversé vraie sous l'effet de l'acide nitreux.

\section{H. Clarke}

Institute of Animal Genetics, Edinburgh (Scotland U.K.), June 21, 1962.

1 J. R. S. FinciAm, Brit. Med. Bull. 18, 14 (1962).

z F. H. C. CRICk, L. BARNett, S. BRENNER, and R. J. WattsToBtN, Nature 192, 1227 (1961).

3 E. Freese, Brookhaven Symp. Biol. 12, 63 (1959).

4 H. G. WrtTMAnN, Naturwiss. 24, 729 (1961).

5 U. LEUpold, Arch. J. Klaus-Stift. Zürich 36, 89 (1961).

- D. G. Catcheside, 10th Symp. Soc. Gen Microbiol. (W. Hayes and R. C. Clowes, Ed., Univ. Press, Cambridge 1960), p. 181.

7 D. G. Catcheside, Proc. Roy, Soc. B. 153, 179 (1960).

* P. E. Hakman, Z. HARTMAN, and D. Serman, J. gen. Microbiol, $29,354(1960)$.

The present experiments (decerebrate, unanaesthetized cats) have revealed the existence of a brain stem centre from which depolarization can be evoked not only in the above mentioned categories of afferents, which are influenced from the pyramidal tract, but also in Ia afferents.

1 J. C. Eccles, R. M. Eccles, and F, Magni, J. Physiol. 159, 147 (1961). - J. C. Eccles, R. G. Kostyuk, and R. F. Schmidt, J. Physiol, 161, 258 (1962). - J. C. Eccles, F. Magnl, and W. D. Wilzis, J. Physiol. 160, 62 (1962), - J. C. Eccles, R. I. Schmidt, and W. D. Willes, J. Physiol, 161, 282 (1962).

2 P. Andersson, J. C. Eccles, and T. A. SeArs, Nature, in press. D. Carpenter, A. Lundere, and U. Norrsell, Exper, 18, 337 (1962). 